\title{
Demand-oriented energy supply by the anaerobic digestion of organic waste
}

\author{
Marco Wehner, \\ Wolfgang Müller, \\ Anke Bockreis \\ University of Innsbruck, \\ Unit of Environmental Engineering, \\ Technikerstrasse 13, \\ 6020 Innsbruck, Austria \\ Email:marco.wehner@uibk.ac.at
}

The share of renewable energy is steadily increasing globally. Nevertheless, power generation from renewable energy sources, such as solar and wind energy, is highly dependent on suitable weather conditions and therefore highly fluctuating. Thus, alternatives to compensate fluctuations in the energy production are necessary. Biogas plants have the potential to balance energy generation fluctuations and work independently from unstable weather. Experiments on laboratory scale showed that the storage of food waste had only a marginal impact on its energy content. A rapid acidification due to a lactic acid fermentation leads to a $\mathrm{pH}$ decrease and concomitant organic acids increase, preserving the stored organic waste. The $\mathrm{pH}$ dropped from initially 4.8 to 4 within the first 2 days of storage. It declined until day 10 to 3.6 and stayed at this level until the end of the experiment. Due to a low $\mathrm{pH}$ and a high VFA concentration, only minor amounts of gas were produced during storage. No formation of explosive gas mixtures was detected during the storage. Therefore, no safety precautions are necessary to avoid danger from explosion. The results obtained in laboratory were confirmed by experiments on real scale. Thus, pre-condition of organic waste for a flexible feeding and demand-oriented energy supply is feasible to balance energy generation fluctuations.

Keywords: anaerobic digestion, biogas, demand-oriented energy supply, organic waste

\section{INTRODUCTION}

In order to counter climate change, it is necessary to fundamentally modify the energy system. With the reorganisation of the energy system, the global share of renewable energy is steadily increasing to lower greenhouse gas emissions from energy generation. In the European Union $20 \%$ of renewable energy should be reached by 2020 concerning the gross final energy con- sumption in the EU [1]. Due to the increasing share of renewable energy, new challenges have to be overcome. Solar and wind technologies are weather dependent. This causes fluctuations in energy generation since there are still outstanding issues related to a large-scale storage of energy. Alternatives are necessary to compensate for fluctuations and to ensure grid stability and supply guarantee. Energy supply by biogas plants can be independently controlled from the weather 
and offers promising solutions for the provision of balancing energy [2].

Various concepts allow a flexible operation of biogas plants and an on-demand energy supply. One concept is the flexible feeding management for a demand-driven energy supply. This relates to the type and amount of the feeding substrates and the time of feeding to the biogas plant. Thus, in times of increased energy demand, biogas production can be temporarily increased by feeding with fast degradable substrates such as sugar beet silage [3].

In order to implement a demand-oriented energy supply by a flexible feeding of biogas plants, it is necessary to store the substrates. Aichinger et al. [4] found that the storage of fresh biowaste on laboratory scale had no negative impact on its energy content and led to preservation. Thus, the aim of this study was to perform a physico-chemical characterisation of fresh food waste during its storage on laboratory scale. Furthermore, the already stored biowaste from a real-scale biogas plant was sampled for a physico-chemical characterisation to study the storage on real scale. The results obtained from the storage experiment of fresh food waste on laboratory scale were compared with the analysis of the already real-scale-stored biowaste even if the input substrates were different.

\section{MATERIAL AND METHODS}

\section{Experiments on laboratory scale}

Fresh food waste was sampled from a canteen, ground with a hand blender Robot Coup MP 450 by adding tap water. The pre-treated fresh food waste was stored over a period of 42 days at $20^{\circ} \mathrm{C}$ in a climatic chamber. 20 -litre plastic containers were used as storage vessels and connected to gas sampling bags. Each plastic container contained approximately $15 \mathrm{~kg}$ of food waste. The experiments were carried out in triplicate.

During the storage, samples of food waste were taken on day $0,1,3,7,21$ and 42 . The physico-chemical analyses were carried out in triplicate. Total solids (TS) and volatile solids (VS) were measured according to European Standards EN 12880 [6] and EN 15169 [7]. Volatile fatty acids (VFA) were analysed with Hach-Lange cuvette tests. The $\mathrm{pH}$ was measured daily on weekdays with a WTW Multi 3420 and pH electrode WTW
Sentix 41. Biomethane potential (BMP) was determined with an Automatic Methane Potential Test System (AMPTS, bioprocess control) over 21 days at $37^{\circ} \mathrm{C}$ according to VDI 4630 [5]. Seeding sludge was collected at a local wastewater treatment plant and stored for one week at $37^{\circ} \mathrm{C}$ prior to the BMP test. It was considered a substrate to inoculum ration of $0.5 \mathrm{~g} \mathrm{VS}_{\text {Substrate }} / \mathrm{g} \mathrm{VS}_{\text {Inoculum }}$ and methane content of $60 \mathrm{Vol}-\%$. The gas in the sampling bags was analysed with Dräger detection tubes for hydrogen $\left(\mathrm{H}_{2}\right)$. A portable gas analyser GA5000 (Geotech) was used to measure methane $\left(\mathrm{CH}_{4}\right)$, carbon dioxide $\left(\mathrm{CO}_{2}\right)$, oxygen $\left(\mathrm{O}_{2}\right)$ and hydrogen sulphide $\left(\mathrm{H}_{2} \mathrm{~S}\right)$. The gas volume was determined with a Ritter drum-type gas meter TG 0.5.

\section{Characterisation of stored biowaste from a real- scale biogas plant}

A sample of already stored source separated organic waste from households (biowaste) was taken from a biogas plant in Vorarlberg, Austria. The biowaste was first shredded, stored for 10 days in a $400 \mathrm{~m}^{3}$ reactor and subsequently pressed with a piston press. A sample of the wet fraction, i.e. feeding substrate, was collected and characterized for TS, VS, pH, VFA and BMP with the methods mentioned before.

\section{RESULTS AND DISCUSSION}

\section{Experiments on laboratory scale}

Fresh food waste was collected at a canteen, ground with water and stored over 42 days at $20^{\circ} \mathrm{C}$ for behaviour characterization during storage. Figure 1 shows the curves of VFA and $\mathrm{pH}$. The $\mathrm{pH}$ of the food waste dropped from initially 4.8 to 4 within in the first two days. It declined until day 10 to 3.6 and stayed at this level until the end of the experiment. In contrast, VFA concentration increased from $3 \mathrm{~g} \mathrm{~L}^{-1}$ at the beginning of the experiment to $13 \mathrm{~g} \mathrm{~L}^{-1}$ on day 42 . This behaviour is due to a lactic acid fermentation, which leads to a decrease in $\mathrm{pH}$ and a strong increase in VFA concentrations. This process is usually applied for silage production in the agricultural sector to preserve maize or grass.

During storage, the content of TS decreased (Table 1). There might be a tendency for a decrease in VS. The low $\mathrm{pH}$ and high VFA concentration led to the production of minor amounts of gas. The highest gas production rate was determined on 


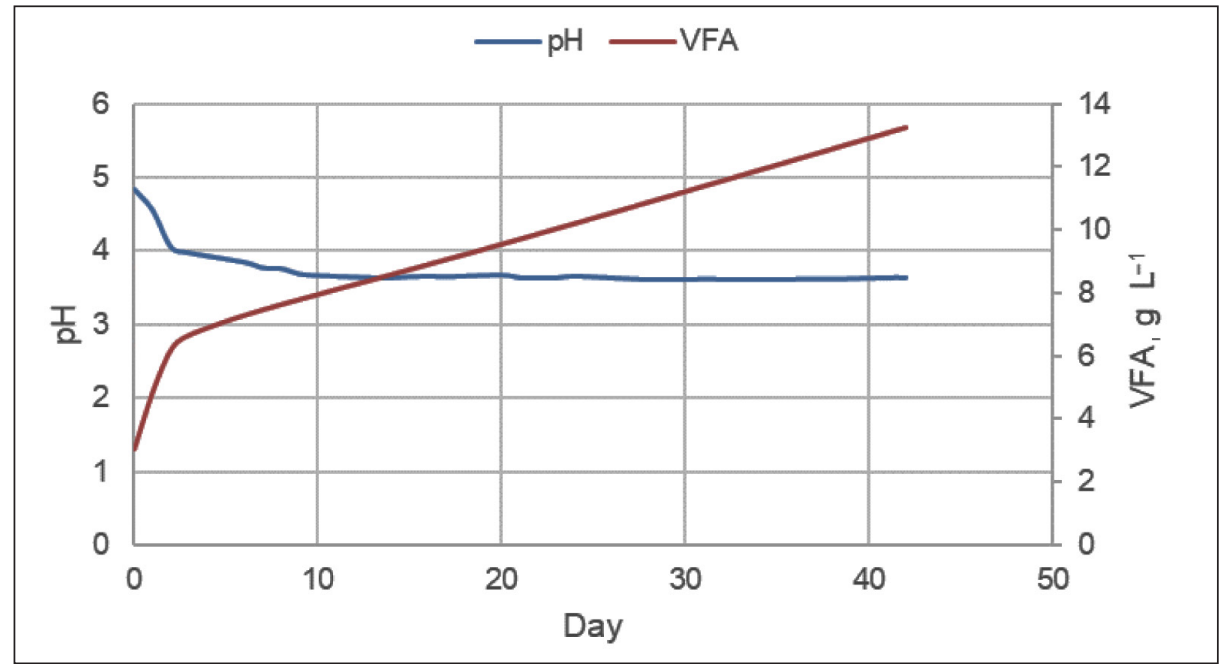

Fig. 1. Volatile fatty acids (VFA) concentration and pH during storage of food waste

Table 1. Total solids (TS) and volatile solids (VS) during storage (mean \pm standard deviation)

\begin{tabular}{c|c|c}
\hline Day & TS (\% FM) & VS (\% TS) \\
\hline 0 & $13.4 \pm 0.02$ & $94.6 \pm 0.29$ \\
\hline 1 & $13.3 \pm 0.11$ & $94.7 \pm 0.37$ \\
\hline 3 & $12.9 \pm 0.21$ & $94.4 \pm 0.28$ \\
\hline 7 & $12.5 \pm 0.29$ & $93.9 \pm 0.17$ \\
\hline 21 & $11.9 \pm 0.55$ & $94.4 \pm 0.62$ \\
\hline 42 & $11.6 \pm 0.14$ & $93.9 \pm 0.10$ \\
\hline
\end{tabular}

day $2\left(0.2 \mathrm{~L} \mathrm{~kg}^{-1}\right.$ fresh matter $\left.(\mathrm{FM}) \mathrm{d}^{-1}\right)$. From day 3 on, the gas production rate steadily decreased to
$0.01 \mathrm{~kg}^{-1} \mathrm{FM} \mathrm{d}^{-1}$ on day 21. $\mathrm{CO}_{2}$ (mean $60 \mathrm{Vol}-\%$ ) was the main gas component. $\mathrm{H}_{2}$ and $\mathrm{CH}_{4}$ were not detected. $\mathrm{H}_{2} \mathrm{~S}$ was found with a maximum concentration of $19 \mathrm{ppm}$. Due to the aforementioned gas concentrations, there is no risk of the formation of explosive gas mixtures. Thereby, no safety precautions are necessary to avoid danger from explosion.

In a further step, the biomethane potential was analysed to investigate the influence of storage on the energy potential of food waste. Figure 2 shows the biomethane potential in $\mathrm{m}_{\mathrm{N}}^{3} \mathrm{CH}_{4} \mathrm{t}^{-1} \mathrm{VS}$ of the fresh and stored food waste (storing day 1, 3,

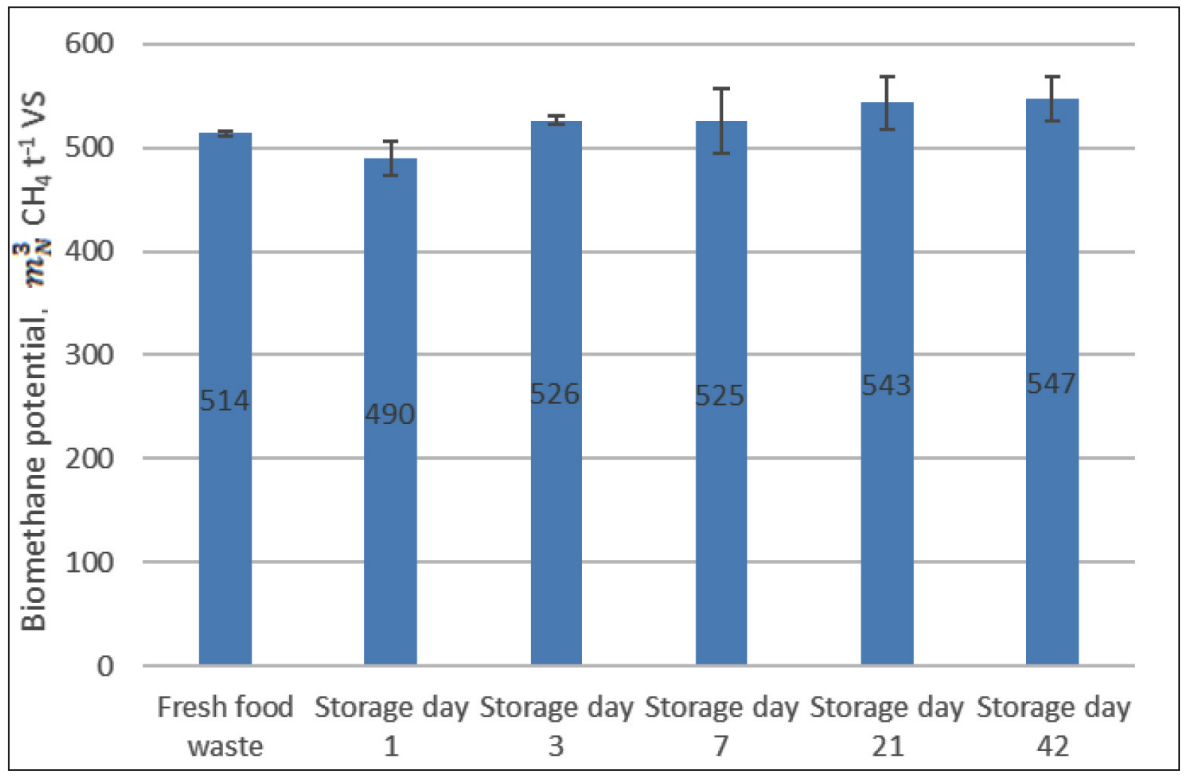

Fig. 2. Biomethane potential of stored food waste (mean \pm standard deviation) 
7, 21 42). Food waste, which was stored for 3, 7, 21 and 42 days reached higher biomethane yields compared to the fresh food waste. Only for food waste, which was stored for one day, a lower biomethane yield in comparison to fresh food waste was observed. Related to Fig. 2, there might be the tendency for improved fermentability because of a higher biomethane potential of stored food waste compared to fresh food waste. A better nutrient availability caused by the acidification and hydrolysis of the stored food waste could be a reason for a higher biomethane potential in relation to the VS content [4]. Figure 3 shows the proportion of the total biomethane production depending on the time of the BMP test. The main fraction of total biomethane production was generated within the first three days of the BMP test which is in line with results from [4]. Therefore, biogas plants can provide energy on demand and in a short time $[3,4]$.

\section{Characterisation of stored biowaste from a real-scale biogas plant}

A sample of stored biowaste was taken from a real-scale biogas plant in November 2017. The pre-treatment of the biowaste sample includ- ed shredding, storing over 10 days and pressing. VFA level reached $30.6 \mathrm{~g} \mathrm{~L}^{-1}$ which shows a strong acidification compared to VFA concentration in laboratory-scale experiments with food waste (Table 2). Despite this fact, the biowaste was efficiently converted into biomethane. The BMP test $\left(482 \mathrm{~m}_{\mathrm{N}}^{3} \mathrm{CH}_{4} \mathrm{t}^{-1} \mathrm{VS}\right)$ was in a similar magnitude as stored food waste from laboratory-scale experiments. Figure 4 shows the proportion of the total biomethane production depending on the time of the BMP test. Within the first 3 days of the BMP test, $75 \%$ of total biomethane production was generated, again, indicating a potential short-termed energy supply by biogas plants (Fig. 4).

Table 2. Physico-chemical characterisation of stored biowaste from a real-scale biogas plant (mean \pm standard deviation)

\begin{tabular}{cc}
\hline Parameter & Result \\
\hline TS $[\% \mathrm{FM}]$ & $13.1 \pm 0.07$ \\
\hline VS $[\% \mathrm{TS}]$ & $77.7 \pm 0.05$ \\
\hline VFA $\left[\mathrm{g} \mathrm{L}^{-1}\right]$ & $30.6 \pm 0.23$ \\
\hline $\mathrm{pH}$ & 4.14 \\
\hline BMP $\left[\mathrm{m}_{\mathrm{N}}{ }^{3}\right.$ Biogas t & \\
\hline $\mathrm{BMP}\left[\mathrm{m}_{\mathrm{N}}{ }^{3} \mathrm{CH}_{4} \mathrm{t}^{-1} \mathrm{VS}\right]$ & 82 \\
\hline
\end{tabular}

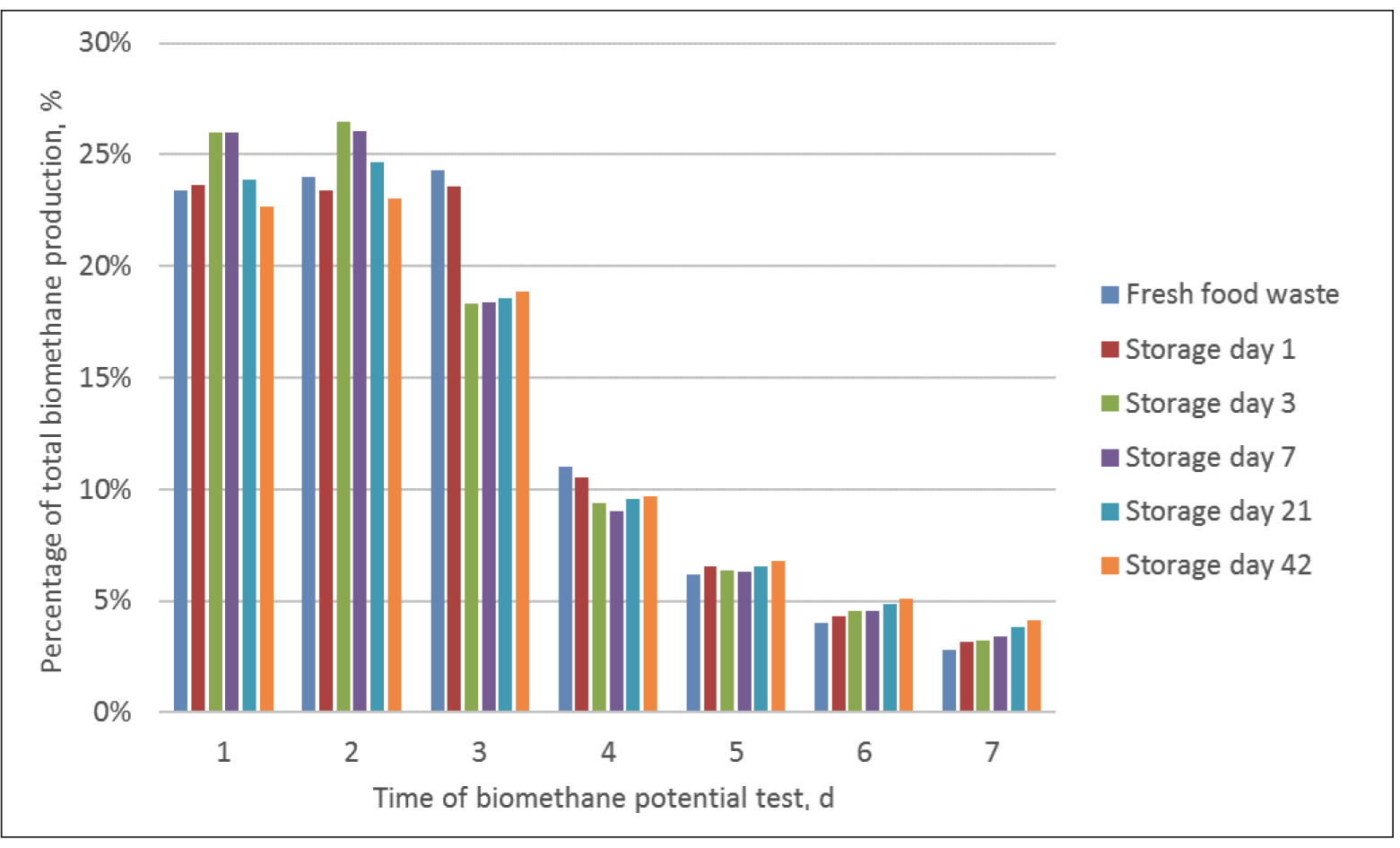

Fig. 3. Total biomethane production depending on BMP test time 


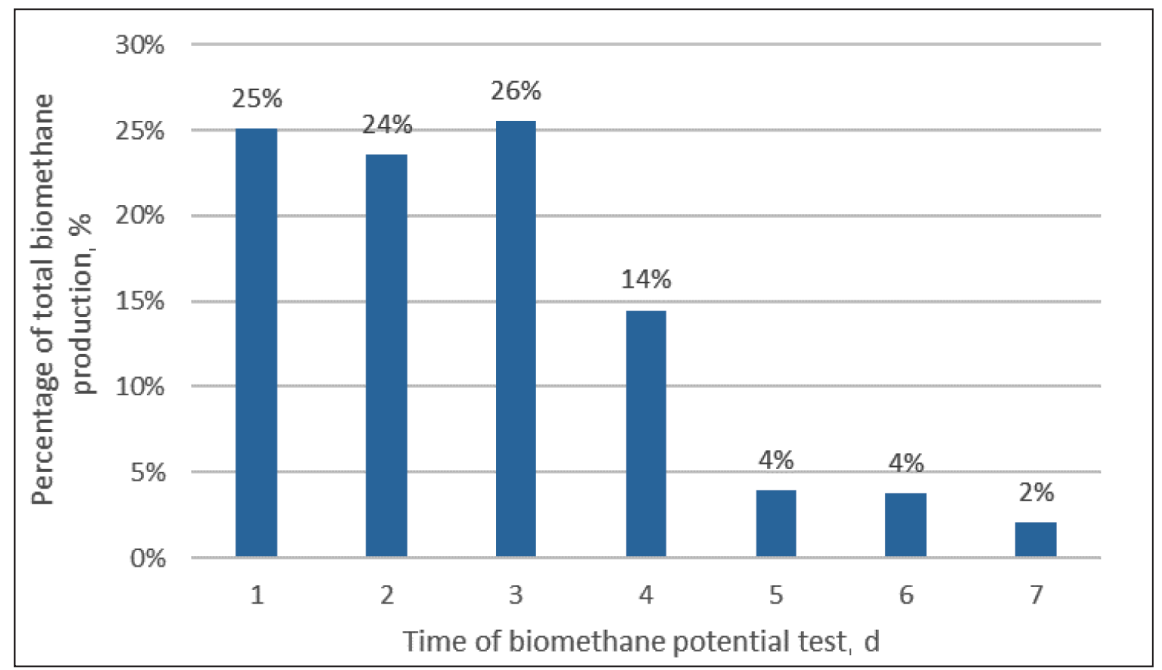

Fig. 4. Total biomethane production depending on BMP test time

\section{CONCLUSIONS}

The storage of food waste and biowaste was investigated on laboratory scale and for a real-scale biogas plant. In both cases, lactic acid fermentation caused a decrease in $\mathrm{pH}$ and a strong increase of VFA. This process, which is also applied for silage production in the agricultural sector, led to the preservation of food waste and biowaste. Due to the acid environment, minor amounts of gas were produced during storage. Because of the gas concentrations the formation of explosive gas mixtures can be excluded.

Storage of organic waste is a promising approach to extend the flexibility of biogas plants for a demand-oriented energy supply. Future research will focus on feeding strategies for a demand-driven energy supply with organic wastes. The aim is to increase the biomethane production by a short-term increased overload to compensate fluctuations in the energy production from renewable energy sources such as wind and solar energy.

Received 1 March 2018 Accepted 10 September 2018

\section{References}

1. Directive 2009/28/EC of the European Parliament and of the Council of 23 April 2009 on the promotion of the use of energy from renew- able sources and amending and subsequently repealing Directives 2001/77/EC and 2003/30/EC.

2. Hahn H., Krautkremer B., Hartmann K., Wachendorf M. Review of concepts for a demand-driven biogas supply for flexible power generation. Renewable and Sustainable Energy Reviews. 2014. Vol. 29. P. 383-393.

3. Mauky E., Fabian Jacobi H., Liebetrau J., Nelles M. Flexible biogas production for demand-driven energy supply - Feeding strategies and types of substrate. Biogas Technology. 2015. Vol. 178. P. 262-269.

4. Aichinger P., Kuprian M., Probst M., Insam H., Ebner C. Demand-driven energy supply from stored biowaste for biomethanisation. Bioresource Technology. 2015. Vol. 194. P. 389-393.

5. VDI 4630, Vergärung organischer Stoffe - Substratcharakterisierung, Probenahme, Stoffdatenerhebung, Gärversuche, (Fermentation of organic materials - Characterization of the substrate, sampling, collection of material data, fermentation tests). Berlin: Beuth Verlag, 2006.

6. EN 12880, Charakterisierung von Schlämmen - Bestimmung des Trockenrückstandes und des Wassergehalts (Determination of sludges $-D e-$ termination of dry residues and water content). Berlin: Beuth Verlag, 2001.

7. EN 15169, Charakterisierung von Abfall - Bestimmung des Glühverlustes in Abfall, Schlamm und Sedimenten (Characterization of waste - Determination of loss on ignition in waste, sludge and sediments). Berlin: Beuth Verlag, 2007. 
Marco Wehner, Wolfgang Müller, Anke Bockreis

\section{PAKLAUSĄ ORIENTUOTAS ENERGIJOS} TIEKIMAS NAUDOJANT ORGANINIŲ

\section{ATLIEKŲ ANAEROBINI SKAIDYMĄ}

\section{Santrauka}

Visame pasaulyje vis didesnę energijos dalį sudaro atsinaujinanti energija. Elektros energijos gamyba iš atsinaujinančių energijos išteklių, pavyzdžiui, saulès ir vejo, labai priklauso nuo tinkamų oro sąlygų, todèl yra kintanti. Reikia ieškoti alternatyvų, kad būtų kompensuoti energijos gamybos svyravimai. Biodujų jègainès gali subalansuoti energijos gamybos svyravimus ir dirbti nepriklausomai nuo besikeičiančių oro sąlygų. Laboratoriniai tyrimai parodė, kad maisto atlieku saugojimas turèjo tik nedidelès itakos ju energijos kiekiui. Dèl pieno rūgšties fermentacijos vyksta staigus rūgštejjimas, lemiantis $\mathrm{pH}$ sumažèji- mą, bei padidejja organinių rūgščių, užkonservuojančių organines atliekas. Per pirmąsias dvi saugojimo dienas $\mathrm{pH}$ sumažèjo nuo 4,8 iki 4. Praejjus dešimčiai dienų jis sumažejo iki 3,6 ir nekito iki eksperimento pabaigos. Dèl mažo pH ir didelès lakiųjų riebalinių rūgščių koncentracijos saugojimo metu buvo gaminami tik nedideli dujų kiekiai. Saugant nebuvo nustatyta sąlygų, kurios turètų ịtakos sprogių dujų mišinių susidarymui. Todèl siekiant išvengti sprogimo pavojaus nereikia imtis jokių atsargumo priemonių. Laboratorijoje gauti rezultatai buvo patvirtinti eksperimentais realiu masteliu. Darytina išvada, kad prielaidos biologinių atliekų lanksčiam it paklausą orientuotam energijos tiekimui yra tinkamos siekiant subalansuoti energijos gamybos svyravimus.

Raktažodžiai: anaerobinis skaidymas, biodujos, i paklausą orientuotas energijos tiekimas, organinès atliekos 